\title{
Stress finite element models for determining the frequencies of free oscillations
}

\section{Определение частот свободных колебаний методом конечных элементов в напряжениях}

\author{
Yu.Ya. Tyukalov, \\ Vyatka State University, Kirov, Russia
}

\author{
Д-р техн. наук, профессор Ю.Я. Тюкалов, \\ Вятский государственный университет, \\ Киров, Россия
}

Key words: finite element method in stresses; free vibration frequency; lower limit values; principle of virtual displacements

\author{
Ключевые слова: метод конечных \\ элементов в напряжениях; частоты \\ свободных колебаний; нижняя граница \\ значений; принцип возможных перемещений
}

\begin{abstract}
Development of calculation methods, allowing determining the lower limits frequencies of free oscillations is actual. Such methods, in combination with the decisions by the method of finite element in displacements, will let to assess the accuracy of the frequencies of free oscillations calculated values. The frequencies of free oscillations constant cross section rods with different supports of the ends are calculating by the stress finite element analysis. The proposed method is based on combination of the additional potential energy functional and the virtual displacements principle. The last is used to construct the equilibrium equations. The solution reduces to finding the minimum of the additional energy functional with constraints in form of the linear algebraic system equilibrium equations. The equilibrium equations, taking into account inertia forces, are writing for the finite element mesh nodes in the directions of coordinate axes. Using the Lagrange multipliers the equilibrium equations are included in the functional. The Lagrange multipliers are the nodes displacements values. Considered two variants of bending moment's approximation on the finite element field: linear and piecewise constant. The free oscillations forms are represented as polygonal lines. According to the proposed method the first three frequencies of free oscillations were defined for constant cross-section rods with different supports of the ends. The calculated values of the frequencies were compared with the exact values. In comparison with the method of finite elements in displacements, it is shown that the proposed method allows to get the opposite bound values for the frequencies of free oscillations.
\end{abstract}

Аннотация. Актуальной является разработка метода расчета конструкций, позволяющего определять нижние границы частот свободных колебаний. Такие методы, в сочетании с решениями по методу конечных элементов в перемещениях, позволят дать оценку точности вычисленных значений частот свободных колебаний. В работе предлагается решение задачи определения частот свободных колебаний стержней постоянного сечения с различными опорами на концах методом конечных элементов в напряжениях. Методика основывается на сочетании функционала дополнительной энергии и принципа возможных перемещений, используемого для построения уравнений равновесия. После дискретизации предметной области, решение задачи сводится к поиску минимума функционала дополнительной энергии деформации при наличии ограничений в виде системы линейных алгебраических уравнений равновесия. Уравнения равновесия, с учетом сил инерции, составляются для узлов сетки конечных элементов по направлениям осей координат и включаются в функционал при помощи множителей Лагранжа, которыми являются величины перемещений узлов. Рассматриваются два варианта аппроксимации изгибающих моментов по области конечного элемента: линейная и кусочнопостоянная. Форма свободных колебаний представляется в виде ломанной линии. По предложенной методике были выполнены расчеты первых трех частот свободных колебаний для стержней постоянного сечения с различными вариантами опирания концов. Выполнено сравнение расчетных величин первых трех частот свободных колебаний с точными значениями. Показано, что предлагаемый метод расчета позволяет получить противоположную, по сравнению с методом конечных элементов в перемещениях, границу значений для частот свободных колебаний. 


\section{Introduction}

Currently, the most common method for determining the frequencies of free oscillations is the finite element displacement analysis [1-12], less often used mixed [13-20] or analytical methods [21-24]. In the article [25] for determining the frequency of free oscillations is used the method of boundary elements. It is known that the method of finite element in displacements gives the more "stiffer" solution and consequently higher values of the free oscillation frequencies compared to accurate values. Displacements which were received by mixed or hybrid methods are approached to the exact values both from below and above. Analytical methods do not have a generality of numerical methods and are applied for a limited group of problems. Actual problem is to develop a method to determine the upper boundary of displacements or low boundary of free oscillations frequencies. This possibility is provided by the functional of additional energy, since the solutions, based on it, are more "flexible", compared with the exact values [1, 2]. But the direct use of this functional is complicated by necessity using the approximating functions that satisfy the differential equations of equilibrium [1]. If the nodal unknowns are self-equilibrated forces, then their choice has difficulties for variety of finite elements. Moreover, these systems should not include the forces to provide a statically determinate structure fixing. If the decision to use the stress function was reached, also there are difficulties to their choice and providing static boundary conditions [2].

In [3] compares the values of the frequencies of the cantilever beams free oscillations, obtained using the ANSYS, and experimentally measured values. To simulate flexural and torsional vibrations used fine mesh flat finite elements. Nonlinear free vibrations of curved shallow shells are investigated using hierarchical finite element in [5]. The decision considers the geometric nonlinearity, shear and rotational inertia. The first and higher frequencies were calculated and the high accuracy of the proposed finite element was shown.

Using the flat joint finite elements for modeling the free beam vibrations is offered in [6]. This approach allows us to consider the effect of shear deformations on the values of the frequencies of free oscillations. Free nonlinear oscillations rods considering shear deformations are considered in [7]. The solution is built using finite elements with independent linear approximations of the longitudinal and transverse displacements, and rotation angles. Hamilton's principle is used for the motion equations. The paper presents the numerical results, which show the effect of vibration amplitude and shear deformation on values of the frequencies of free vibrations of beams with different support conditions.

Precision triangular element, considering the shear deformations, is presented in [12] for bending plates. When the stiffness matrix is formed, the finite element is divided into three triangles. The proposed element allows us to calculate the frequencies of free vibrations with high precision. In [13] isoparametric quadrilateral finite element with eight nodes is used to study the free oscillations of thin and thick plates. It examines the different schemes of construction mass matrices and examples of the calculation of rectangular plates. It is concluded that the use of the diagonal mass matrix provides a high accuracy of frequencies. Various forms of the equations of the rods dynamics and significance accurate determination of the free oscillations frequencies spectrum were shown in [26, 27]. The articles [28-33] devoted to research of the various variational formulations for deciding nonlinear and thin-wall rods systems by finite element method in displacements.

In [16] as the nodal unknowns of finite element method are accepted forces, bending and torsional moments, corresponding deformations and curvatures. Distribution of forces to finite element area is taken to be linear. The system of equations consists of the equilibrium equations of nodes, which are formed by means of the principle of possible displacements and strain compatibility equations, which are written using the static-geometric analogy. The number of unknowns is reduced using the known relationship between stresses (moments) and strains (curvatures). There are examples of calculating the bending plates, shallow shells and plane elasticity problems.

Solution of the free vibrations of a rectangular, clamped along the contour plate using the expansion of displacements in Taylor, McLaren's series is presented in [21]. The article compares the frequencies of free oscillations of plates with different aspect ratio, obtained using the proposed method with those of other authors.

Thus, the main part of work is aimed at improving the method of finite elements in displacements. Some work focused on the development of finite element methods for some constructions in the form of the method of forces or stresses. Still actual is problem of constructing solutions by finite element method in stresses, which will have the same universality, as the finite element method in displacement, and will allow obtaining of alternative solutions abroad. 


\section{Methods}

In [34-38], based on the additional energy functional and the principle of virtual displacements, were built solving the building structures problems by using the stress finite element analysis. Using for the approximations of stresses (forces) in the field of finite element constant or piecewise constant functions we will get the upper border of displacements. In general, the solution of the problem reduces to finding the minimum of the additional energy functional (1) in the presence of limitations in the form of equilibrium equations of nodes (2).

$$
\begin{aligned}
\Pi^{c}=U^{*}+V^{*} & =\frac{1}{2} \int\{\sigma\}^{T}[E]^{-1}\{\sigma\} d \Omega-\int\{T\}^{T}\{\bar{\Delta}\} d S \rightarrow \min , \\
& \left\{C_{i, x}\right\}^{\mathrm{T}}\left\{\bar{\sigma}_{i}\right\}+\bar{P}_{i, x}=0, \quad i \in \Xi_{x}, \\
& \left\{C_{i, y}\right\}^{\mathrm{T}}\left\{\bar{\sigma}_{i}\right\}+\bar{P}_{i, y}=0, \quad i \in \Xi_{y}, \\
& \left\{C_{i, z}\right\}^{\mathrm{T}}\left\{\bar{\sigma}_{i}\right\}+\bar{P}_{i, z}=0, \quad i \in \Xi_{z} .
\end{aligned}
$$

where $U^{*}$ - additional energy of the strains, $V^{*}$ - potential boundary forces corresponding to the specified displacements [1]; $\left\{\bar{\sigma}_{i}\right\}$ - vector of unknown node stresses (forces) of finite elements adjacent to the node $i ; \Xi_{x}, \Xi_{y}, \Xi_{z}$ - sets of nodes that have free displacements along the axes $\mathrm{X}, \mathrm{Y} и \mathrm{Z}$ respectively; $\{\bar{\Delta}\}-$ vector given displacements of nodes; $\{T\}$ - vector boundary forces; $S$ - boundary surface, on which the displacement nodes are given; $\left\{C_{i, x}\right\},\left\{C_{i, x}\right\},\left\{C_{i, z}\right\}$ - vectors, whose elements are the coefficients (multipliers) of the unknown node stresses (forces) of finite elements adjacent to the node $i ; \bar{P}_{i, x}, \bar{P}_{i, y}, \bar{P}_{i, z}$ - external loads potential corresponding to the virtual unit displacements of the node $i$ along axes $x, y, z$ respectively. The equilibrium equations (2) are formed by means of the principle of virtual displacements for all admissible displacements of nodes along the coordinate axes. If node united more than two finite elements, then you must add the equations of equilibrium moments about the axes for this node. Below, we will view only straight rods, so the equilibrium equations of moments are not considered.

To go to the problem unconstrained minimization, we use the method of Lagrange multipliers. Then the advanced additional energy functional takes the following form: 1).

Consider the process of constructing resolving equations on the example of a flat rod system (Fig.

$$
. \Pi_{c}^{u}=U^{*}+V^{*}+\sum_{j=x, y, z} \sum_{i \in \Xi_{j}} u_{i, j}\left(\left\{C_{i, j}\right\}^{\mathrm{T}}\left\{\bar{\sigma}_{i}\right\}+\bar{P}_{i, j}\right) \rightarrow \min ,
$$

where $u_{i, j}$ - the actual displacement of the node $i$ towards $j$, which is the Lagrange multiplier for the corresponding equilibrium equation. When using functional $(3)$ there is no need to use a stress field, which satisfy the differential equations of equilibrium, as required by the principle of minimum additional energy. The equilibrium equations will be carried out in discrete sense - in the form of the equilibrium equations of the finite element mesh nodes. (Fig. 1).

Consider the process of constructing resolving equations on the example of a flat rod system

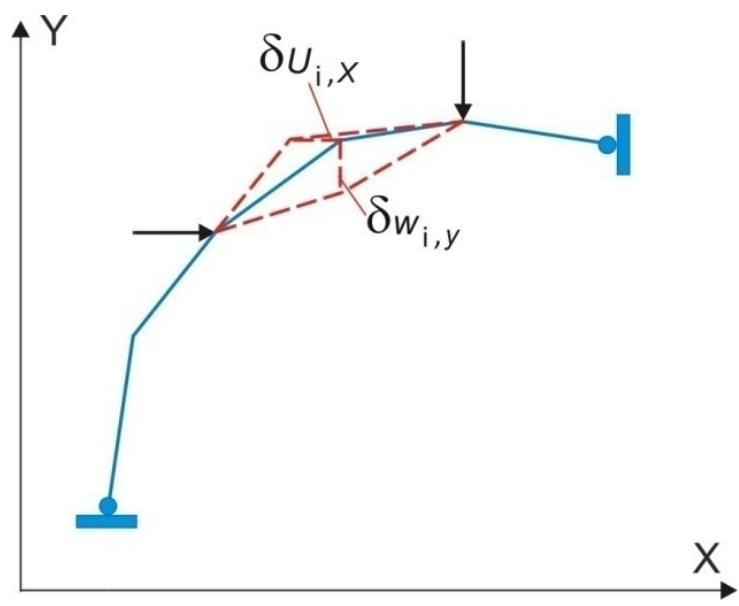

Figure 1. Flat rod system. Virtual displacements of the node

Тюкалов Ю.Я. Определение частот свободных колебаний методом конечных элементов в напряжениях // Инженерно-строительный журнал. 2016. № 7(67). С. 39-54. 
The longitudinal forces and bending moments are the nodal unknowns $\left\{\bar{\sigma}_{i}\right\}=\left\{\begin{array}{l}N_{i} \\ M_{i}\end{array}\right\}$ (Fig. 2).

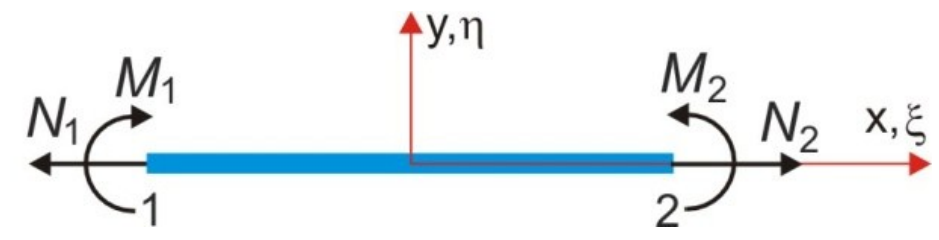

Figure 2. The rod finite element unknowns

Consider the linear approximations of forces and moments in the field of finite element

$$
N=\sum_{i=1}^{2} L_{i} N_{i}, \quad M=\sum_{i=1}^{2} L_{i} M_{i},
$$

where:

$$
L_{i}=\frac{\left(1+\xi_{i} \xi\right)}{2}, \xi=\frac{2 x}{l^{e}}, i=1.2,
$$

where $l^{e}$ - length of the finite element. $L_{i}$ - linear function-forms, recorded by using the relative coordinate $\xi$. The $\xi, x$ coordinates are measured from the center of the finite element. Thus, $\xi_{1}=-1$ and $\xi_{2}=1$. For the constant cross section rod, the additional energy is the sum of two integrals

$$
U_{e}^{*}=\frac{1}{2} \int_{0}^{l^{e}} \frac{N(x)^{2} d x}{E A^{e}}+\frac{1}{2} \int_{9}^{l^{e}} \frac{M(x)^{2} d x}{E I^{e}},
$$

where $E$ - modulus of elasticity; $A^{e}$ - cross-sectional area; $I^{e}-$ cross-sectional moment of inertia. Denote the vector of nodal unknowns for finite element $\left\{\bar{\sigma}^{e}\right\}^{T}=\left(N_{1} M_{1} N_{2} M_{2}\right)$. Then, after integration we get that

$$
U_{e}^{*}=\frac{1}{2}\left\{\bar{\sigma}^{e}\right\}^{T}\left[B^{e}\right]\left\{\bar{\sigma}^{e}\right\}
$$

where:

$$
\left[B^{e}\right]=\left[\begin{array}{cccc}
\frac{l^{e}}{3 E A^{e}} & 0 & \frac{l^{e}}{6 E A^{e}} & 0 \\
0 & \frac{l^{e}}{3 E I^{e}} & 0 & \frac{l^{e}}{6 E I^{e}} \\
\frac{l^{e}}{6 E A^{e}} & 0 & \frac{l^{e}}{3 E A^{e}} & 0 \\
0 & \frac{l^{e}}{6 E I^{e}} & 0 & \frac{l^{e}}{3 E I^{e}}
\end{array}\right] .
$$

If the approximations of forces and moments are piecewise constant functions, then

$$
\left[B^{e}\right]=\left[\begin{array}{cccc}
\frac{l^{e}}{2 E A^{e}} & 0 & 0 & 0 \\
0 & \frac{l^{e}}{2 E I^{e}} & 0 & 0 \\
0 & 0 & \frac{l^{e}}{2 E A^{e}} & 0 \\
0 & 0 & 0 & \frac{l^{e}}{2 E I^{e}}
\end{array}\right] .
$$

Global additional energy matrix $\left[B^{e}\right]$ for the whole system is formed from a matrix $[B]$ for each finite element, in accordance with global indexes of unknowns. 


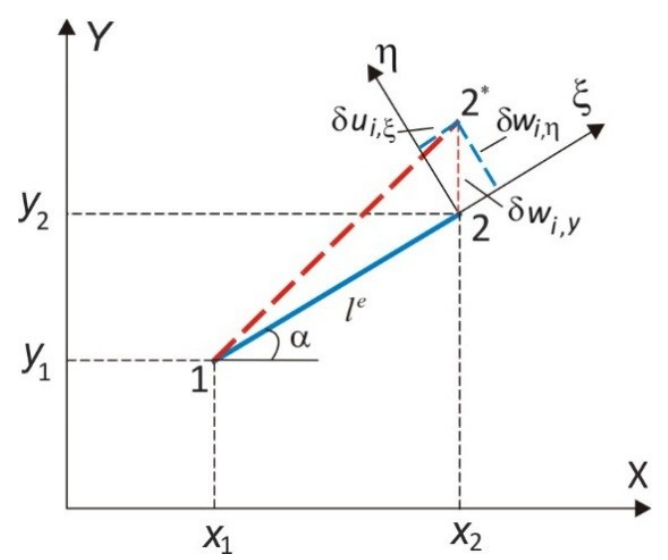

Figure 3. Local and global coordinate system

To form the equilibrium equations of nodes is introduced local coordinate system $\xi o \eta$, associated with the considered finite element (Fig. 3). The possible displacements of node $\delta \bar{u}_{i, x}, \delta \bar{w}_{i, y}$ along the global axes $X$ and $Y$ can be represented as the geometric sum of the displacements $\delta \bar{u}_{i, \xi}, \delta \bar{w}_{i, \eta}$ along the local axes. Possible displacement along axis $Y$ causes the following displacements:

$$
\delta \bar{u}_{i, \xi}=\delta \bar{w}_{i, y} \sin \alpha, \quad \delta \bar{w}_{i, \eta}=\delta \bar{w}_{i, y} \cos \alpha .
$$

Displacement $\delta \bar{u}_{i, x}$ can be replaced by the following possible displacements along the axes of the local coordinate system:

$$
\begin{gathered}
\delta \bar{u}_{i, \xi}=\delta \bar{u}_{i, x} \cos \alpha, \quad \delta \bar{w}_{i, \eta}=-\delta \bar{u}_{i, x} \sin \alpha, \\
\cos \alpha=\frac{x_{2}-x_{1}}{l^{e}}, \quad \sin \alpha=\frac{y_{2-} y_{1}}{l^{e}} .
\end{gathered}
$$

Displacements of points of the finite elements, abutting to this node, are linear functions (Fig. 4a). Therefore, displacement causes the constant deformation

$$
\delta \varepsilon=\frac{\delta \bar{u}_{i, \xi}}{l^{e}}
$$

Then the energy deformation of the finite element in view of (4) is

$$
\delta \bar{U}_{i, \xi}^{e}=\int_{0}^{l^{e}} N(x) \delta \varepsilon d x=\left(N_{1}+N_{2}\right) \frac{\delta \bar{u}_{i, \xi}}{2} .
$$

If displacement of the node is directed along the normal $\delta \bar{w}_{i, \eta}$, then the finite element moved as rigid body (Fig. 4b), so that the axis curvature of the rod is zero. In this case, the deformations energy equal the work of nodal moments:

$$
\delta \bar{U}_{i, \eta}^{e}=\left(M_{2}-M_{1}\right) \varphi=\frac{\left(M_{2}-M_{1}\right)}{l^{e}} \delta \bar{w}_{2, \eta}
$$

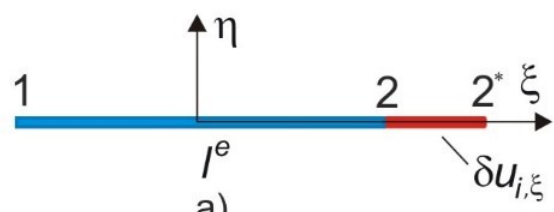

a)

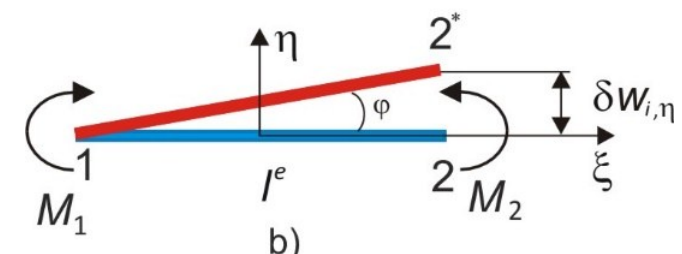

b)

Figure 4. Possible displacements in the local coordinate system

Тюкалов Ю.Я. Определение частот свободных колебаний методом конечных элементов в напряжениях // Инженерно-строительный журнал. 2016. № 7(67). С. 39-54. 
In general, the expression (14) can be written in relative coordinates of the nodes.

$$
\delta \bar{U}_{i, \eta}^{e}=\frac{\delta \bar{w}_{i, \eta} \xi_{i}}{l^{e}}\left(\xi_{1} M_{1}+\xi_{2} M_{2}\right)=\frac{\delta \bar{w}_{i, \eta} \xi_{i}}{l^{e}} \sum_{J=1}^{2} \xi_{J} M_{J} .
$$

The relative coordinates of the nodes have the following values: $\xi_{1}=-1, \xi_{2}=1$. Using the expressions (13), (15) and (10), the energy of deformation from possible displacement of the node along the global $\mathrm{X}$-axis of coordinates is written in the following form:

$$
\delta \bar{U}_{i, x}^{e}=\frac{\cos \alpha}{2}\left(N_{1}+N_{2}\right)-\frac{\xi_{i} \sin \alpha}{l^{e}}\left(\xi_{1} M_{1}+\xi_{2} M_{2}\right) .
$$

In vector notation

$$
\delta \bar{U}_{i, x}^{e}=\left\{C_{i, x}^{e}\right\}^{T}\left\{\bar{\sigma}^{e}\right\},
$$

Equation (17) can be expressed by the vector unknowns of all finite elements, adjacent to the node.

$$
\delta \bar{U}_{i, x}^{e}=\left\{C_{i, x}^{e g}\right\}^{T}\left\{\bar{\sigma}_{i}\right\}
$$

The elements of the vector (18) are moved in a pre-zeroed global vector $\left\{C_{i, x}^{e g}\right\}$ in accordance with global numeration of unknowns. The size of the vector $\left\{C_{i, x}^{e g}\right\}$ is equal to the number of nodal unknowns. For all finite elements, adjacent to the node $i$

$$
\delta \bar{U}_{i, x}=\sum_{e}\left\{C_{i, x}^{e g}\right\}^{T}\left\{\bar{\sigma}_{i}\right\}=\left\{C_{i, x}\right\}^{T}\left\{\bar{\sigma}_{i}\right\}
$$

The potential of external forces at possible unit displacement along the $\mathrm{X}$-axis

$$
\delta \bar{V}_{i, x}=\bar{P}_{i, x}=P_{i, x}+\frac{1}{2} \sum_{e} q_{x}^{e} l^{e},
$$

where: $P_{i, x}$ - projection of the force on the X-axis; $q_{x}^{e}$ - evenly distributed load for the finite element, adjacent to the node $i$. Equilibrium equation of the node along the $X$ axis will be have the standard form

$$
\left\{C_{i, x}\right\}^{T}\left\{\bar{\sigma}_{i}\right\}+\bar{P}_{i, x}=0 \text {. }
$$

For possible displacement of the node $\delta \bar{w}_{i, y}=1$ along the $\mathrm{Y}$-axis

$$
\delta \bar{U}_{i, y}^{e}=\frac{\sin \alpha}{2}\left(N_{1}+N_{2}\right)+\frac{\xi_{i} \cos \alpha}{l^{e}}\left(\xi_{1} M_{1}+\xi_{2} M_{2}\right) .
$$

In vector notation

$$
\begin{gathered}
\delta \bar{U}_{i, y}^{e}=\left\{C_{i, y}^{e}\right\}^{T}\left\{\bar{\sigma}^{e}\right\}, \\
\left\{C_{i, y}^{e}\right\}=\left\{\begin{array}{c}
\frac{\sin \alpha}{2} \\
\frac{\xi_{i} \xi_{1} \cos \alpha}{l^{e}} \\
\frac{\sin \alpha}{2} \\
\xi_{i} \xi_{2} \cos \alpha \\
l^{e}
\end{array}\right\} .
\end{gathered}
$$

The potential of external forces at possible unit displacement along the $\mathrm{Y}$-axis

$$
\delta \bar{V}_{i, y}=\bar{P}_{i, y}=P_{i, y}+\frac{1}{2} \sum_{e} q_{y}^{e} l^{e},
$$

Equilibrium equation of the node along the $\mathrm{Y}$-axis will be like (22).

Tyukalov Yu.Ya. Stress finite element models for determining the frequencies of free oscillations. Magazine of Civil Engineering. 2016. No. 7. Pp. 39-54. doi: 10.5862/MCE.67.5 
Consider the free oscillations of constant cross-section rods. To illustrate the method simply supported rod, divided into three finite elements, is showed in Figure 5. The nodal displacements and bending moments will be unknowns.

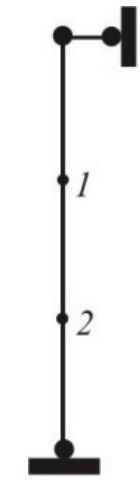

a)

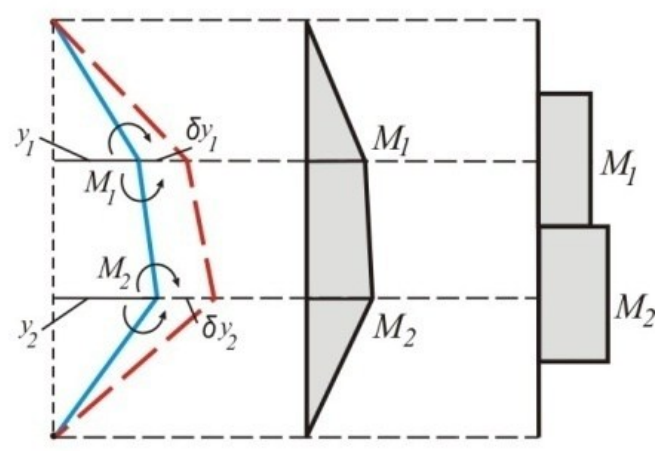

b)

d)

Figure 5. Simply supported rod: a) finite elements;

b) a form of free oscillations; c) linear approximation of moments;

d) piecewise constant approximation of moments

The length of the finite element $-l^{e}$, bending stiffness $-E l$, the mass per unit length of rod $-m$. In Figure 6, for any finite element, the following notation: $M_{1}, M_{2}$ - the internal bending moments; $R_{1}, R_{2}-$ nodal reactions corresponding bending moments; $F_{1}, F_{2}$ - nodal reactions, corresponding inertia forces $f(x, t)$. The longitudinal vibrations are absent.

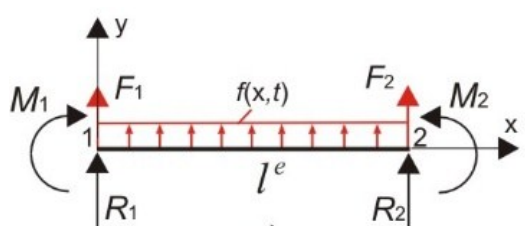

a)

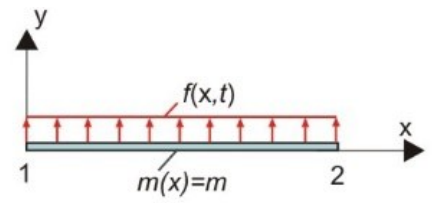

b)

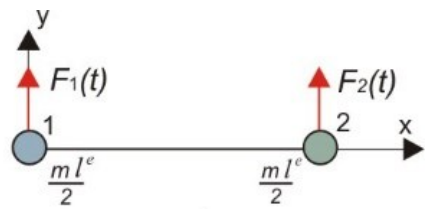

c)

Figure 6. The finite element: a) internal forces and nodal reactions;

b) dynamic finite element model with distributed mass;

c) dynamic finite element model with concentrated masses

Using the principle of virtual displacements or equations of equilibrium moments, nodal reactions $R_{1}, R_{2}$ can be expressed through the nodal bending moments. For example, reaction $R_{2}$ is the derivative of the virtual deformations energy $\delta \bar{U}_{i, \eta}^{e}$ by virtual displacement $\delta \bar{w}_{2, \eta}$ (see (14)). Expression for the finite element nodal forces in the matrix form is written as

$$
\left\{\begin{array}{l}
R_{1} \\
R_{2}
\end{array}\right\}=\left[\begin{array}{cc}
\frac{1}{l^{e}} & \frac{-1}{l^{e}} \\
\frac{-1}{l^{e}} & \frac{1}{l^{e}}
\end{array}\right]\left\{\begin{array}{l}
M_{1} \\
M_{2}
\end{array}\right\} \text { or }\left\{R^{e}\right\}=\left[A^{e}\right]\left\{M^{e}\right\} .
$$

Matrix $\left[A^{e}\right]$ is static equations matrix. Vector $\left\{R^{e}\right\}$ is vector of unknown nodal bending moments for finite element. The form of the rod oscillations is approximated by broken line (Fig. $5 b$ ). In the field of finite element, displacements of points are represented by a linear function. Thus, the distributed forces of inertia are determined by expression (28):

$$
f(\mathrm{x}, t)=-m \ddot{y}=m \omega^{2}\left(y_{1}\left(1-\frac{x}{l^{e}}\right)+y_{2} \frac{x}{l^{e}}\right) \sin (\omega t) .
$$

Then, excluding $\sin (\omega t)$, we obtain nodal reactions corresponding distributed inertia forces 


$$
\left\{\begin{array}{l}
F_{1} \\
F_{2}
\end{array}\right\}=\left[\begin{array}{cc}
\frac{\omega^{2} m l^{e}}{3} & \frac{\omega^{2} m l^{e}}{6} \\
\frac{\omega^{2} m l^{e}}{6} & \frac{\omega^{2} m l^{e}}{3}
\end{array}\right]\left\{\begin{array}{l}
y_{1} \\
y_{2}
\end{array}\right\} \text { or }\left\{F^{e}\right\}=\left[B^{e}\right]\left\{y^{e}\right\} .
$$

If the mass concentrated in the nodes, we obtain a diagonal matrix

$$
\left[B^{e}\right]=\left[\begin{array}{cc}
\frac{\omega^{2} m l^{e}}{2} & 0 \\
0 & \frac{\omega^{2} m l^{e}}{2}
\end{array}\right]
$$

Additional energy of the finite element strains is expressed as the integral

$$
\Pi^{* \mathrm{e}}=\frac{1}{2} \int_{0}^{l} \frac{M(x)^{2}}{E I} d x .
$$

After integration, we obtain the following matrix expression:

$$
\Pi^{* \mathrm{e}}=\frac{1}{2}\left\{M^{e}\right\}^{T}\left[D^{e}\right]\left\{M^{e}\right\}
$$

Flexibility matrix $\left[D^{e}\right]$ is written in two versions $-\left[D^{e}\right]_{\text {lin }}$ for linear (Fig. 5c) and $\left[D^{e}\right]_{\text {pic }}$ for piecewise constant (Fig. 5d) approximations of the moments:

$$
\left[D^{e}\right]_{\text {lin }}=\left[\begin{array}{cc}
\frac{l}{3 E I} & \frac{l}{6 E I} \\
\frac{l}{6 E I} & \frac{l}{3 E I}
\end{array}\right],\left[D^{e}\right]_{p i c}=\left[\begin{array}{cc}
\frac{l}{2 E I} & 0 \\
0 & \frac{l}{2 E I}
\end{array}\right] \text {. }
$$

By forming from local vectors and matrices (with index e) according to the unknown's numeration, we obtain similar global matrix and vector for the whole system. Expressing through them functional (3) we get:

$$
\Pi_{c}^{u}=\frac{1}{2}\{M\}^{T}[D]\{M\}+\{y\}^{T}([A]\{M\}+\{F\}) \rightarrow \min .
$$

By equating to zero the derivatives of the (34) along the vectors $\{M\}$ and $\{y\}$, we obtain

$$
\begin{gathered}
{[D]\{M\}+[A]^{T}\{y\}=0,} \\
{[A]\{M\}+\{F\}=0 .}
\end{gathered}
$$

The vector of inertia forces expressed through the global matrix $[B]$, then the system of linear homogeneous equations takes the following form:

$$
\left\{\begin{array}{c}
{[D]\{M\}+[A]^{T}\{y\}=0,} \\
{[A]\{M\}+[B]\{y\}=0 .}
\end{array}\right.
$$

By equating to zero the determinant of the system (36), we find the frequencies of the free oscillations $\omega$. The number of unknowns of the system (36) can be reduced. To do this, we express the vector $\{M\}$ from the first matrix equation in system (36) and substitute it in the second equation. Then we will get the system of equations (37). The system (38) is obtained by expression vector $\{y\}$ from the second matrix equation in (36).

$$
\begin{aligned}
& \left(-[A][D]^{-1}[A]^{T}+[B]\right)\{y\}=0, \\
& \left(-[A]^{T}[B]^{-1}[A]+[D]\right)\{M\}=0 .
\end{aligned}
$$

The system (37) have advantage, if we will use the piecewise constant approximation of moments along length of the finite element. Then the matrix $[D]$ consists of the matrices $\left[D^{e}\right]_{\text {pic }}$ and the matrix $[D]^{-1}$ elements are calculated analytically. If we used only concentrated masses, then matrix $[B]$ will take the diagonal form. In this case, it is easier to use the system of equations (38). If matrices $[D]$ and $[B]$ does not have the diagonal form, the frequency must be determined by the system (36), which is Tyukalov Yu.Ya. Stress finite element models for determining the frequencies of free oscillations. Magazine of Civil Engineering. 2016. No. 7. Pp. 39-54. doi: 10.5862/MCE.67.5 
bigger than the system (37) or (38). If we calculate the frequency by means an iterative process, it would require more computing operations.

\section{Results and Discussion}

To evaluate the accuracy determination of the frequencies by the method proposed above, we have been calculated first three frequencies of the free oscillations for constant cross-section rods with different supports of the ends. To simplify the analysis length, bending stiffness and mass per meter of the rods was taken equal to unity. In the calculations was used Mathcad 14.0 program.

Graphics in Figures 7-14 show comparison of the calculated values of the first three frequencies of free oscillations with the exact values. The first version of the figures (green line -1 ) corresponds to a linear approximation moments along length of the finite element, the second - a piecewise constant moments (blue line - 2).

The results show, that by using the concentrated masses (Fig. 7-10) frequencies calculation values are approached to exact values from below, when we use both linear and piecewise constant approximation of the moments.

If the mass of the rod is evenly distributed (Fig. 11-14) and moments are piecewise constants, the frequencies are approached to exact values from below. When using linear approximation moments - the calculated frequencies are approached to exact values from above, as in the case of using the finite element method in displacement.

The proposed method of calculation allows you to get the opposite bound values for the frequencies of free oscillations, in comparison with the finite element analysis in displacements. This requires use the concentrated masses and linear or piecewise constant approximation of the moments. Also, we can use the distributed mass in combined with piecewise constant approximation of the moments.

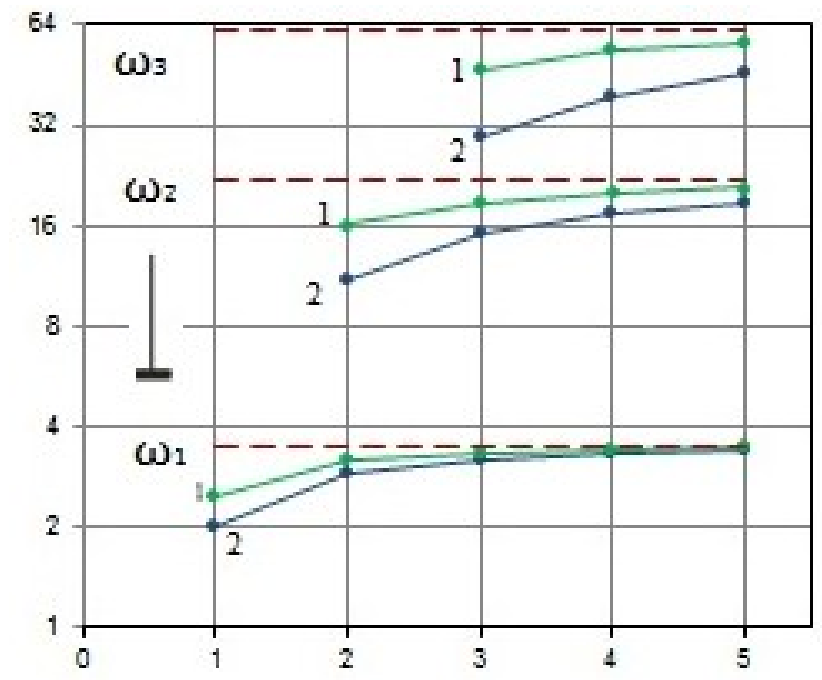

Figure 7. The frequency of free oscillations of a cantilever rod depending on the number of grid nodes. The mass of the rod concentrated at the nodes

Тюкалов Ю.Я. Определение частот свободных колебаний методом конечных элементов в напряжениях // Инженерно-строительный журнал. 2016. № 7(67). С. 39-54. 


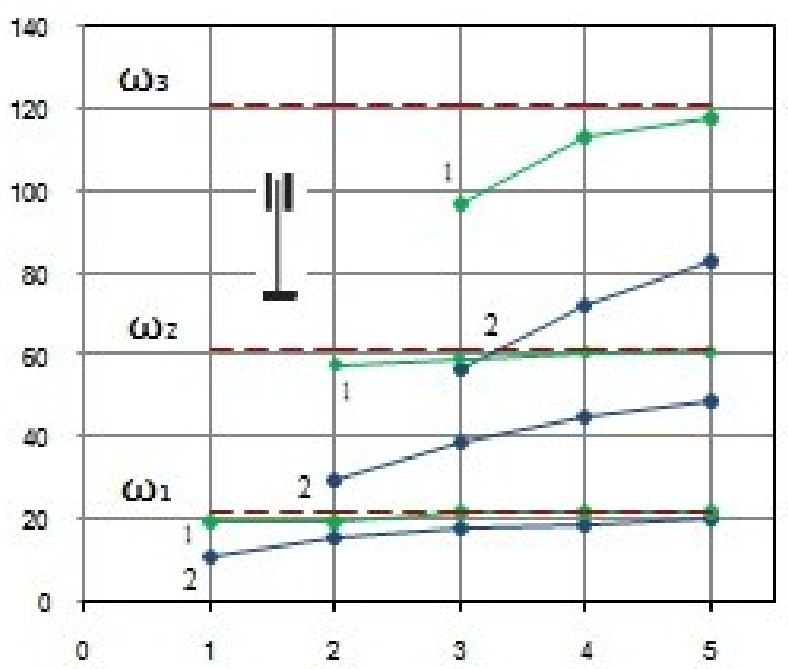

Figure 8. The frequencies of free oscillations of a clamped rod depending on the number of grid nodes. The mass of the rod concentrated at the nodes

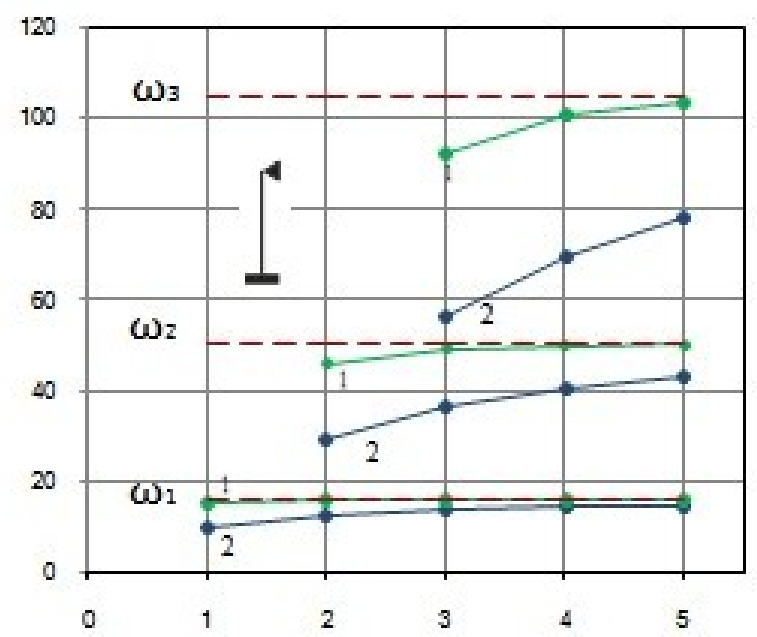

Figure 9. The frequencies of free oscillations of a rod with one clamped and one hinge supports depending on the number of grid nodes. The mass of the rod is concentrated at the nodes

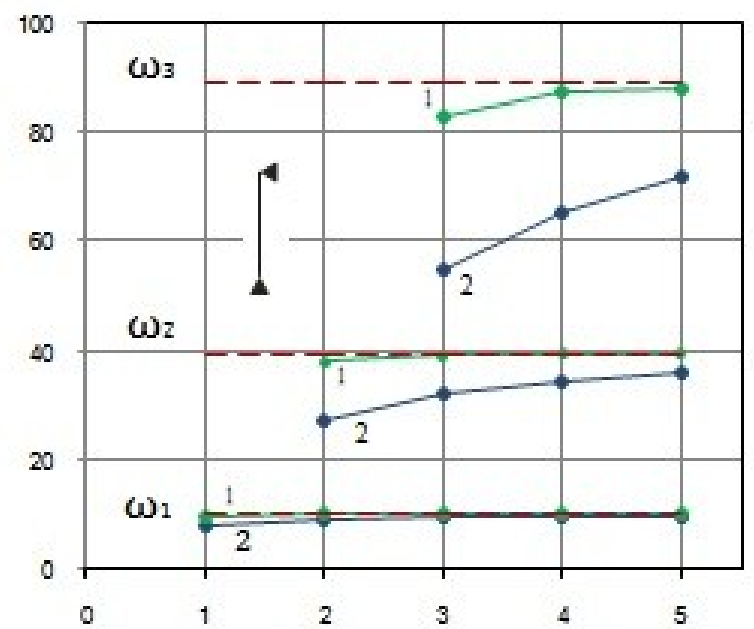

Figure 10. The frequency of free oscillations of simply supported rod depending on the number of grid nodes. The mass of the rod is concentrated at the nodes

Tyukalov Yu.Ya. Stress finite element models for determining the frequencies of free oscillations. Magazine of Civil Engineering. 2016. No. 7. Pp. 39-54. doi: 10.5862/MCE.67.5 


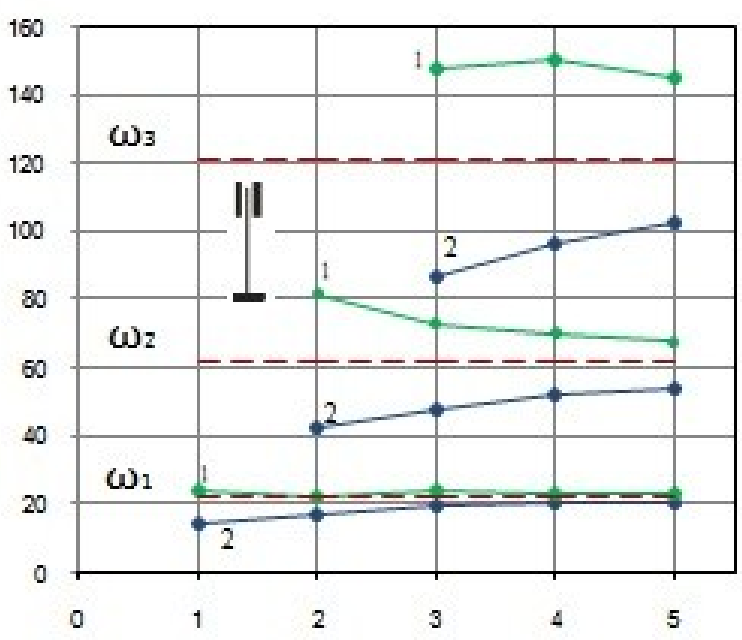

Figure 11. Frequencies of free oscillations of the clamped rod, depending on the number of grid nodes. The mass of the rod is evenly distributed

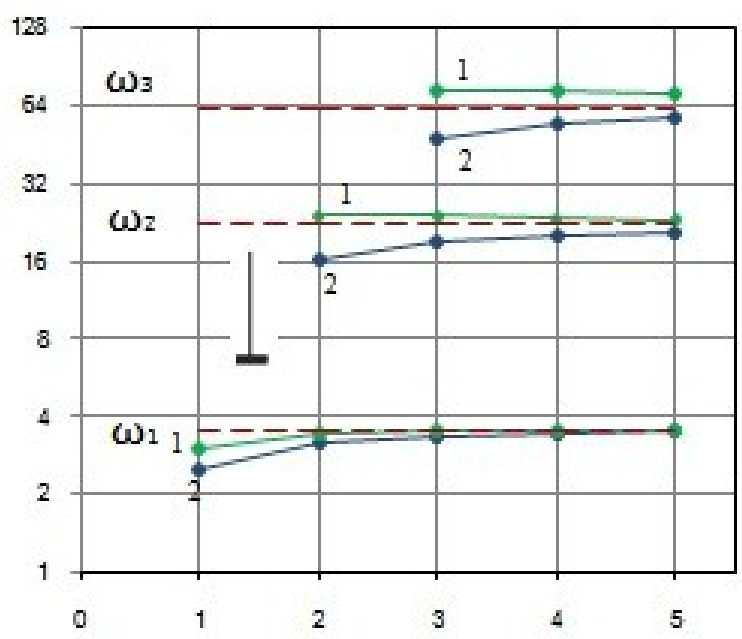

Figure 12. The frequency of free oscillations of a cantilever rod depending on the number of grid nodes. The mass of the rod is evenly distributed

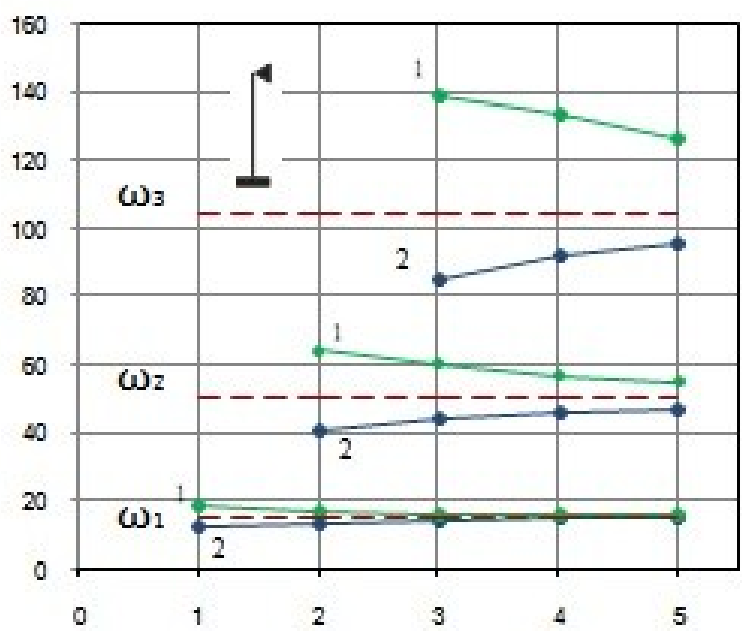

Figure 13. The frequency of free oscillations of a rod with one clamped and one hinged supports depending on the number of grid nodes. The mass of the rod is evenly distributed

Тюкалов Ю.Я. Определение частот свободных колебаний методом конечных элементов в напряжениях // Инженерно-строительный журнал. 2016. № 7(67). С. 39-54. 


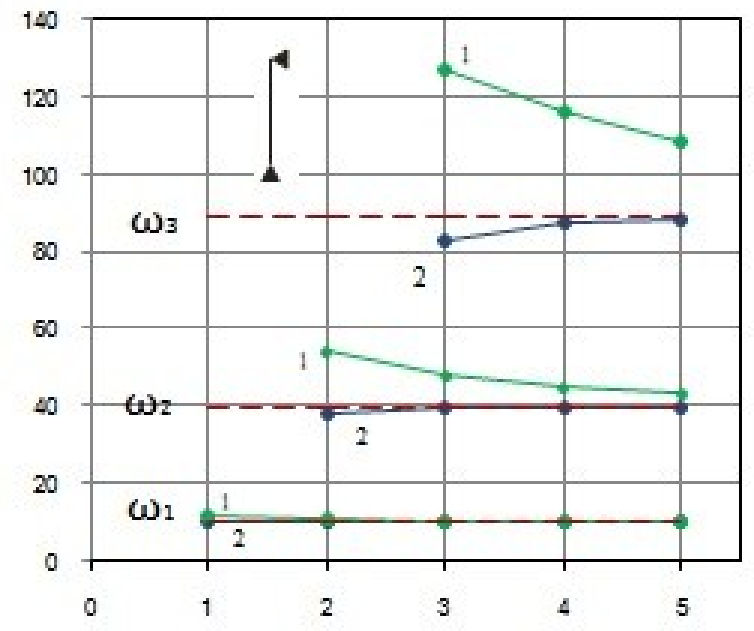

Figure 14. The frequency of free oscillations of hinged rod depending on the number of grid nodes. The mass of the rod is evenly distributed

Tables 1-4 show the calculations results and their accuracy estimates that were received by using the concentrated masses and linear approximation of the moments. Table 5 show the calculation results accuracy estimates. Number of grid nodes is equal five. In Table 5 rods are designated as: $1-$ cantilever rod; 2 - clamped rod; 3 - rod with one clamped and one hinged supports; 4 - hinged rod.

The above data in Tables 1-4 show, that by crushing grid the results accuracy is increasing quite quickly. For cantilever beam, the calculating error is reducing from $30.2 \%$ to $1.8 \%$ for the first frequency, from 26.2 to 5.9 for the second frequency and from 23.8 to 9.3 for the third frequency. Obviously, for a more accurate calculation of the second and third frequencies values is required more nodes. For other supports of the rods, the accuracy of the calculated frequency values is substantially higher and it is satisfactory for all three frequencies even at five nodes.

In Table 5 the accuracy estimates of the calculated results in percentage for the grid with five nodes are shown. The highest precision is achieved by using a linear approximation of the bending moments and concentrated masses. Less accurate results are obtained by using a piecewise constant approximation points and distributed masses. More nodes of the grid are required to achieve high accuracy of the results using piecewise constant approximations of moments and concentrated masses, but in this case, as in the previous two, calculated values of the frequencies are approaching to the exact values from below. When using linear approximation moments and distributed mass, the calculated frequencies are approached to exact values from above and are required more nodes for achieve high accuracy of the results.

Table 1. The results for cantilever rod (Fig. 7 green line - 1)

\begin{tabular}{|c|c|c|c|c|c|c|}
\hline \multirow{2}{*}{$\begin{array}{c}\text { Number } \\
\text { of grid } \\
\text { nodes }\end{array}$} & \multicolumn{2}{|c|}{$\begin{array}{c}\text { Exact value } \\
\boldsymbol{\omega}_{\mathbf{1}}=\mathbf{3 . 5 1 6} \mathbf{~ r a d} / \mathbf{s e c}\end{array}$} & \multicolumn{2}{c|}{$\begin{array}{c}\text { Exact value } \\
\boldsymbol{\omega}_{\mathbf{2}}=\mathbf{2 2 . 0 3 5} \mathbf{~ r a d} / \mathbf{s e c}\end{array}$} & \multicolumn{2}{c|}{$\boldsymbol{\omega}_{\mathbf{3}}=\mathbf{6 1 . 7 0 1} \mathbf{~ r a d} / \mathbf{s e c}$} \\
\cline { 2 - 7 } & $\begin{array}{c}\text { Calculated } \\
\text { values }\end{array}$ & Error \% & $\begin{array}{c}\text { Calculated } \\
\text { values }\end{array}$ & Error \% & $\begin{array}{c}\text { Calculated } \\
\text { values }\end{array}$ & Error \% \\
\hline 1 & 2.449 & 30.3 & - & - & - & - \\
\hline 2 & 3.156 & 10.2 & 16.258 & 26.2 & - & - \\
\hline 3 & 3.346 & 4.8 & 18.886 & 14.3 & 47.028 & 23.8 \\
\hline 4 & 3.418 & 2.8 & 20.090 & 8.8 & 53.202 & 13.8 \\
\hline 5 & 3.453 & 1.8 & 20.734 & 5.9 & 55.953 & 9.3 \\
\hline
\end{tabular}

Tyukalov Yu.Ya. Stress finite element models for determining the frequencies of free oscillations. Magazine of Civil Engineering. 2016. No. 7. Pp. 39-54. doi: 10.5862/MCE.67.5 
Table 2. The results for clamped rod (Fig. 8 green line - 1)

\begin{tabular}{|c|c|c|c|c|c|c|}
\hline \multirow{2}{*}{$\begin{array}{l}\text { Number } \\
\text { of grid } \\
\text { nodes }\end{array}$} & \multicolumn{2}{|c|}{$\begin{array}{c}\text { Exact value } \\
\omega_{1}=22.373 \mathrm{rad} / \mathrm{sec}\end{array}$} & \multicolumn{2}{|c|}{$\begin{array}{c}\text { Exact value } \\
\omega_{2}=61.67 \mathrm{rad} / \mathrm{sec}\end{array}$} & \multicolumn{2}{|c|}{$\begin{array}{c}\text { Exact value } \\
\omega_{3}=120.903 \mathrm{rad} / \mathrm{sec}\end{array}$} \\
\hline & $\begin{array}{c}\text { Calculated } \\
\text { values }\end{array}$ & Error \% & $\begin{array}{c}\text { Calculated } \\
\text { values }\end{array}$ & Error \% & $\begin{array}{c}\text { Calculated } \\
\text { values }\end{array}$ & Error \% \\
\hline 1 & 19.596 & 12.4 & - & - & - & - \\
\hline 2 & 20.069 & 10.3 & 57.65 & 6.5 & - & - \\
\hline 3 & 22.302 & 0.3 & 59.20 & 4.0 & 97.40 & 19.4 \\
\hline 4 & 22.350 & 0.1 & 60.90 & 1.25 & 113.12 & 6.4 \\
\hline 5 & 22.364 & 0.04 & 61.39 & 0.45 & 118.01 & 2.4 \\
\hline
\end{tabular}

Table 3. The results for rod with one clamped and one hinge supports (Fig. 9 green line - 1)

\begin{tabular}{|c|c|c|c|c|c|c|}
\hline \multirow{2}{*}{$\begin{array}{l}\text { Number } \\
\text { of grid } \\
\text { nodes }\end{array}$} & \multicolumn{2}{|c|}{$\begin{array}{c}\text { Exact value } \\
\omega_{1}=15.418 \mathrm{rad} / \mathrm{sec}\end{array}$} & \multicolumn{2}{|c|}{$\begin{array}{c}\text { Exact value } \\
\omega_{2}=49.964 \mathrm{rad} / \mathrm{sec}\end{array}$} & \multicolumn{2}{|c|}{$\begin{array}{c}\text { Exact value } \\
\omega_{3}=104.248 \mathrm{rad} / \mathrm{sec}\end{array}$} \\
\hline & $\begin{array}{c}\text { Calculated } \\
\text { values }\end{array}$ & Error \% & $\begin{array}{c}\text { Calculated } \\
\text { values }\end{array}$ & Error \% & $\begin{array}{c}\text { Calculated } \\
\text { values }\end{array}$ & Error \% \\
\hline 1 & 14.832 & 3.8 & - & - & - & - \\
\hline 2 & 15.349 & 0.45 & 45.632 & 8.7 & - & - \\
\hline 3 & 15.402 & 0.10 & 49.054 & 1.8 & 91.53 & 12.2 \\
\hline 4 & 15.412 & 0.04 & 49.683 & 0.56 & 100.43 & 3.7 \\
\hline 5 & 15.416 & 0.01 & 49.851 & 0.23 & 102.82 & 1.4 \\
\hline
\end{tabular}

Table 4. The results for simply supported rod (Fig. 10 green line - 1)

\begin{tabular}{|c|c|c|c|c|c|c|}
\hline \multirow{2}{*}{$\begin{array}{c}\text { Number } \\
\text { of grid } \\
\text { nodes }\end{array}$} & \multicolumn{2}{|c|}{$\begin{array}{c}\text { Exact value } \\
\boldsymbol{\omega}_{\mathbf{1}}=\mathbf{9 . 8 6 9} \mathbf{~ r a d} / \mathbf{s e c}\end{array}$} & \multicolumn{2}{c|}{$\begin{array}{c}\text { Exact value } \\
\boldsymbol{\omega}_{\mathbf{2}}=\mathbf{3 9 . 4 7 8} \mathbf{~ r a d} / \mathbf{s e c}\end{array}$} & \multicolumn{2}{c|}{$\boldsymbol{\omega}_{\mathbf{3}}=\mathbf{8 8 . 8 2 6} \mathbf{~ r a d} / \mathbf{s e c}$} \\
\cline { 2 - 7 } & $\begin{array}{c}\text { Calculated } \\
\text { values }\end{array}$ & Error \% & $\begin{array}{c}\text { Calculated } \\
\text { values }\end{array}$ & Error \% & $\begin{array}{c}\text { Calculated } \\
\text { values }\end{array}$ & Error \% \\
\hline 1 & 9.798 & 0.7 & - & - & - & - \\
\hline 2 & 9.859 & 0.1 & 38.184 & 3.3 & - & - \\
\hline 3 & 9.867 & 0.02 & 39.192 & 0.7 & 83.21 & 6.3 \\
\hline 4 & 9.868 & 0.01 & 39.381 & 0.25 & 87.18 & 1.8 \\
\hline 5 & 9.869 & 0 & 39.436 & 0.1 & 88.18 & 0.7 \\
\hline
\end{tabular}

Table 5. Accuracy estimate of the calculated results in percentage

\begin{tabular}{|c|c|c|c|c|c|}
\hline$\omega$ & Rod & $\begin{array}{c}M-\text { linear } \\
m-\text { distributed }\end{array}$ & $\begin{array}{c}M-\text { linear } \\
m-\text { concentrated }\end{array}$ & $\begin{array}{c}\text { M - piecewise } \\
\text { constant } \\
\text { m - distributed }\end{array}$ & $\begin{array}{c}M-\text { piecewise } \\
\text { constant } \\
\text { m - concentrated }\end{array}$ \\
\hline \multirow{4}{*}{$\omega_{1}$} & 1 & 0.3 & 1.8 & 1.8 & 3.2 \\
\hline & 2 & -2.7 & 0.04 & 7.8 & 10.1 \\
\hline & 3 & -2.6 & 0.01 & 3.5 & 5.9 \\
\hline & 4 & -2.3 & 0 & 0 & 2.3 \\
\hline \multirow{4}{*}{$\omega_{2}$} & 1 & -4.0 & 5.9 & 6.0 & 14.4 \\
\hline & 2 & -9.8 & 0.45 & 12.3 & 20.5 \\
\hline & 3 & -9.8 & 0.23 & 6.0 & 14.3 \\
\hline & 4 & -9.4 & 0.1 & 0.1 & 8.8 \\
\hline \multirow{4}{*}{$\omega_{3}$} & 1 & -13.2 & 9.3 & 9.3 & 26.5 \\
\hline & 2 & -19.7 & 2.4 & 15.6 & 31.0 \\
\hline & 3 & -21.0 & 1.4 & 8.5 & 25.2 \\
\hline & 4 & -21.6 & 0.7 & 0.7 & 18.9 \\
\hline
\end{tabular}




\section{Conclusions}

1. The proposed method of calculation allows getting the opposite bound values (bottom values) for the frequencies of free oscillations, in comparison with the finite element analysis in displacements.

2. The highest precision is achieved by using a linear approximation of the bending moments and concentrated masses. For grid with five nodes the maximal calculating error is $1.8 \%-$ for first frequency, $5.9 \%$ - for second frequency and $9.3 \%$ - for third frequency. The calculated values of the frequencies are approaching to the exact values from below.

3. Use the concentrated masses and linear or piecewise constant approximation of the moments or the distributed mass in combined with piecewise constant approximation of the moments, the calculated values of the frequencies are approaching to the exact values from below.

4. Using linear approximation moments and distributed mass, the calculated frequencies are approached to exact values from above. For grid with five nodes the maximal calculating error is $2.7 \%-$ for first frequency, $9.8 \%$ - for second frequency and $21.6 \%$ - for third frequency.

\section{References}

1. Gallager R. Metod konechnykh elementov. Osnovy [The finite element method. Foundation]. Moscow: Mir, 1984 428 p. (rus)

2. Zenkevich O. Metod konechnykh elementov $v$ tekhnike [The finite element method in the technique]. Moscow: Mir, 1975. 541 p. (rus)

3. Chaphalkar S.P., Khetre S.N., Meshram A.M. Modal analysis of cantilever beam structure using finite element analysis and experimental analysis. American Journal of Engineering Research. 2015. Vol. 4. No. 10. Pp. 178-185.

4. Xing Y., Liu B. High-accuracy differential quadrature finite element method and its application to free vibrations of thin plate with curvilinear domain. International Journal for Numerical Methods in Engineering. 2009. Vol. 80. No. 13. Pp. 1718-1742.

5. Ribeiro P. A hierarchical finite element for geometrically non-linear vibration of doubly curved, moderately thick isotropic shallow shells. International Journal for Numerical Methods in Engineering. 2003. Vol. 56. No. 5. Pp. 715738.

6. Hirdaris S.E., Lees A.W. A conforming unified finite element formulation for the vibration of thick beams and frames. International Journal for Numerical Methods in Engineering. 2005. Vol. 62. No. 4. Pp. 579-599.

7. Rakowski J., Guminiak M. Non-linear vibration of Timoshenko beams by finite element method. Journal of Theoretical and Applied Mechanics. 2015. Vol. 53. No. 3. Pp. 731-743.

8. Ghorbe O., Casimir J.B., Hammami L., Tawfiq I., Haddar M. Dynamic stiffness formulation for free orthotropic plates. Journal of Sound and Vibration. 2015. No. 346. Pp. 361-375.

9. Klanner M., Ellermann K. Wave based method for the steady-state vibrations of thick plates. Journal of Sound and Vibration. 2015. No. 345. Pp. 146-161.

10. Keglin B.G., Tsukanova Ye.S. Dinamicheskiy konechnyy element v stroitelnoy mekhanike [Dynamic finite element in the structural mechanics]. Structural Mechanics and Analysis of Constructions. 2015. No. 4. Pp. 41-45. (rus)

11. Sukhoterin M.V. Sobstvennyye kolebaniya pryamougolnoy konsolnoy plastiny [Free oscillations a rectangular cantilever plate]. Structural Mechanics and Analysis of Constructions. 2014. No. 2. Pp. 24-26. (rus)

12. Nguyen-Thoi T., Phung-Van P., Nguyen-Xuan H., ThaiHoang C. A cell-based smoothed discrete shear gap method using triangular elements for static and free vibration analyses of Reissner-Mindlin plates. International Journal for Numerical Methods in Engineering. 2012. Vol. 91. No. 7. Pp. 705-741.

\section{Литература}

1. Галлагер Р. Метод конечных элементов. Основы. М.: Мир, 1984. 428 с

2. Зенкевич О. Метод конечных элементов в технике. М. Мир, 1975. 541 с

3. Chaphalkar S. P., Khetre S.N., Meshram A.M. Modal analysis of cantilever beam structure using finite element analysis and experimental analysis // American Journal of Engineering Research. 2015. Vol. 4. № 10. Pp. 178-185.

4. Xing Y., Liu B. High-accuracy differential quadrature finite element method and its application to free vibrations of thin plate with curvilinear domain // International Journal for Numerical Methods in Engineering. 2009. Vol. 80. № 13. Pp. 1718-1742.

5. Ribeiro P. A hierarchical finite element for geometrically non-linear vibration of doubly curved, moderately thick isotropic shallow shells // International Journal for Numerical Methods in Engineering. 2003. Vol. 56. № 5. Pp. 715-738.

6. Hirdaris S.E., Lees A.W. A conforming unified finite element formulation for the vibration of thick beams and frames // International Journal for Numerical Methods in Engineering. 2005. Vol. 62. № 4. Pp. 579-599.

7. Rakowski J., Guminiak M. Non-linear vibration of Timoshenko beams by finite element method // Journal of Theoretical and Applied Mechanics. 2015. Vol. 53. № 3. Pp. 731-743.

8. Ghorbe O., Casimir J.B., Hammami L., Tawfiq I., Haddar M. Dynamic stiffness formulation for free orthotropic plates // Journal of Sound and Vibration. 2015. № 346. Pp. 361375.

9. Klanner M., Ellermann K. Wave based method for the steady-state vibrations of thick plates // Journal of Sound and Vibration. 2015. № 345. Pp. 146-161.

10. Кеглин Б.Г., Цуканова Е.С. Динамический конечный элемент в строительной механике // Строительная механика и расчет сооружений. 2015. № 4. С. 41-45.

11. Сухотерин М.В. Собственные колебания прямоугольной консольной пластины // Строительная механика и расчет сооружений. 2014. № 2. С. 24-26.

12. Nguyen-Thoi T., Phung-Van P., Nguyen-Xuan H., ThaiHoang C. A cell-based smoothed discrete shear gap method using triangular elements for static and free vibration analyses of Reissner-Mindlin plates // International Journal for Numerical Methods in Engineering. 2012. Vol. 91. № 7. Pp. 705-741.

13. Rock T.A., Hinton E. A finite element method for the free vibration of plates allowing for transverse shear deformation // Comuters and Structers. 1976. Vol. 6. No. 1

Tyukalov Yu.Ya. Stress finite element models for determining the frequencies of free oscillations. Magazine of Civil Engineering. 2016. No. 7. Pp. 39-54. doi: 10.5862/MCE.67.5 
13. Rock T.A., Hinton E. A finite element method for the free vibration of plates allowing for transverse shear deformation. Comuters and Structers. 1976. Vol. 6. No. 1. Pp. 37-44.

14. Kulikov G.M., Plotnikova S.V. A hybrid-mixed four-node quadrilateral plate element based on sampling surfaces method for 3D stress analysis. International Journal for Numerical Methods in Engineering. 2016. Vol. 108. No. 1. Pp. 26-54.

15. Stupishin L.U., Nikitin K.E. Mixed finite element for geometrically nonlinear orthotropic shallow shells of revolution. Advanced Materials Research. 2014. No. 919. Pp. 1299-1302.

16. Gienke E. A simple "mixed" method for plate and shell problems. Nuclear Engineering and Design. 1974. Vol. 29. No. 1. Pp. 141-155.

17. Wolf J.P. Stress finite-element models with independent strain. International Journal for Numerical Methods in Engineering. 1975. No. 5. Pp. 555-568.

18. Tottenham H., Barony S.Y. Mixed finite element formulation for geometrically non-linear analysis of shells of revolution. International Journal for Numerical Methods in Engineering. 1978. Vol. 12. No. 2. Pp. 195-201.

19. Wolf J.P. Alternate hybrid stress finite element models. International Journal for Numerical Methods in Engineering. 1975. Vol. 9. No. 3. Pp. 601-615.

20. Ishakov V.I. Primeneniye metoda sil dlya rascheta pologikh obolochek tipa giperbolicheskogo paraboloida [Application of the forces method for calculating of shallow shells such as hyperbolic paraboloid]. Structural Mechanics and Analysis of Constructions. 1982. No. 3. Pp. 22-27. (rus)

21. Onwuka D.O., Ibearugbulem O.M., Abamara A.C., Njoku C.F., Agbo S.I. Free vibration analysis of an alroundclamped rectangular thin orthotropic plate using TaylorMclaurin shape function. American Journal of Engineering Research. 2016. Vol. 5. No. 5. Pp. 190-197.

22. Kamgar R., Rahgozar R. A simple approximate method for free vibration analysis of framed tube structures. The Structural Design of Tall and Special Buildings. 2013. Vol. 22. No. 2. Pp. 217-234.

23. Rogalevich V.V. Metod pereopredelennoy vnutrenney kollokatsii $v$ zadachakh prochnosti, ustoychivosti i kolebaniy plastin i obolochek [Method overdetermined internal collocation in problems of strength, stability and vibrations of plates and shells]. Structural Mechanics and Analysis of Constructions. 1982. No. 5. Pp. 33-38. (rus)

24. Akimov P.A., Zolotov A.B. Discrete-continual finite element method of analysis for three-dimensional curvilinear civil and unilateral constraints. International Journal for Computational Civil and Structural Engineering. 2003. Vol. 1. No. 5. Pp. 10-27.

25. Wang H.-C., Banerjee P.K. Free vibration of axisymmetric solids by BEM using particular integrals. International Journal for Numerical Methods in Engineering. 1990. Vol. 29. No. 5. Pp. 985-1001.

26. Lalin V.V. Razlichnyye formy nelineynoy dinamiki uprugikh sterzhney [Various forms of the nonlinear dynamics of elastic rods]. Trudy SPbGPU. 2004. No. 489. Pp.121128. (rus)

27. Denisov G.V., Lalin V.V. O sploshnom spektre kolebaniy balochnykh elementov konstruktsii pri vysokochastotnykh vozdeystviyakh [On the continuous spectrum of beam elements vibrations structure at high impacts]. Magazine of Civil Engineering. 2012. No. 1(27). Pp. 91-97. (rus)

28. Lalin V.V., Rybakov V.A., Morozov S.A. Issledovaniye konechnykh elementov dlya rascheta tonkostennykh sterzhnevykh system [Study of finite elements for the calculation of thin-walled rod systems]. Magazine of Civil Engineering. 2012. No. 1(27). Pp. 53-73. (rus)

29. Lalin V.V., Zdanchuk Ye.V., Kushova D.A., Rozin L.A.
Pp. 37-44

14. Kulikov G.M., Plotnikova S.V. A hybrid-mixed four-node quadrilateral plate element based on sampling surfaces method for 3D stress analysis // International Journal for Numerical Methods in Engineering. 2016. Vol. 108. № 1 Pp. 26-54.

15. Stupishin L.U., Nikitin K.E. Mixed finite element for geometrically nonlinear orthotropic shallow shells of revolution // Advanced Materials Research. 2014. № 919. Pp. 1299-1302.

16. Gienke E. A simple "mixed" method for plate and shell problems // Nuclear Engineering and Design. 1974. Vol. 29. № 1. Pp. 141-155.

17. Wolf J.P. Stress finite-element models with independent strain // International Journal for Numerical Methods in Engineering. 1975. № 5. Pp. 555-568.

18. Tottenham H., Barony S.Y. Mixed finite element formulation for geometrically non-linear analysis of shells of revolution // International Journal for Numerical Methods in Engineering. 1978. Vol. 12. № 2. Pp. 195-201.

19. Wolf J.P. Alternate hybrid stress finite element models // International Journal for Numerical Methods in Engineering. 1975. Vol. 9. № 3. Pp. 601-615.

20. Ишаков В. И. Применение метода сил для расчёта пологих оболочек типа гиперболического параболоида // Строительная механика и расчёт сооружений. 1982. № 3. C. 22-27.

21. Onwuka D.O., Ibearugbulem O.M., Abamara A.C., Njoku C.F., Agbo S.I. Free vibration analysis of an alroundclamped rectangular thin orthotropic plate using TaylorMclaurin shape function // American Journal of Engineering Research. 2016. Vol. 5. № 5. Pp. 190-197.

22. Kamgar R., Rahgozar R. A simple approximate method for free vibration analysis of framed tube structures // The Structural Design of Tall and Special Buildings. 2013. Vol. 22. № 2. Pp. 217-234.

23. Рогалевич В.В. Метод переопределенной внутренней коллокации в задачах прочности, устойчивости и колебаний пластин и оболочек // Строительная механика и расчёт сооружений. 1982. № 5. С. 33-38.

24. Akimov P.A., Zolotov A.B. Discrete-continual finite element method of analysis for three-dimensional curvilinear civil and unilateral constraints // International Journal for Computational Civil and Structural Engineering. 2003 Vol. 1. № 5. Pp. 10-27.

25. Wang H.-C., Banerjee P.K. Free vibration of axisymmetric solids by BEM using particular integrals // International Journal for Numerical Methods in Engineering. 1990. Vol. 29. № 5. Pp. 985-1001.

26. Лалин В.В. Различные формы нелинейной динамики упругих стержней // Труды СПбГПУ. 2004. № 489. С. $121-128$.

27. Денисов Г.В., Лалин В.В. О сплошном спектре колебаний балочных элементов конструкции при высокочастотных воздействиях // Инженерностроительный журнал. 2012. № 1(27). С. 91-97.

28. Лалин В.В., Рыбаков В.А., Морозов С.А. Исследование конечных элементов для расчета тонкостенных стержневых систем // Инженерно-строительный журнал. 2012. № 1(27). С. 53-73.

29. Лалин В.В., Зданчук Е.В., Кушова Д.А., Розин Л.А. Вариационные постановки нелинейных задач с независимыми вращательными степенями свободы // Инженерно-строительный журнал. 2015. № 4(56). C. 54-65.

30. Лалин В.В., Розин Л.А., Кушова Д.А. Вариационная постановка плоской задачи геометрически нелинейного деформирования и устойчивости упругих стержней // Инженерно-строительный журнал. 2013. № 1(36). C. 87-96.

31. Lalin V., Rybakov V., Sergey A. The finite elements for

Тюкалов Ю.Я. Определение частот свободных колебаний методом конечных элементов в напряжениях // Инженерно-строительный журнал. 2016. № 7(67). С. 39-54. 
Variatsionnyye postanovki nelineynykh zadach $\mathrm{s}$ nezavisimymi vrashchatelnymi stepenyami svobody[Variational formulation of nonlinear problems with independent rotational degrees of freedom]. Magazine of Civil Engineering. 2015. No. 4(56). Pp. 54-65. (rus)

30. Lalin V.V., Rozin L.A., Kushova D.A. Variatsionnaya postanovka ploskoy zadachi geometricheski nelineynogo deformirovaniya i ustoychivosti uprugikh sterzhney [The variational formulation of the plane problem of geometrically nonlinear deformation and stability of elastic rods]. Magazine of Civil Engineering. 2013. No. 1(36). Pp.87-96. (rus)

31. Lalin V., Rybakov V., Sergey A. The finite elements for design of frame of thin-walled beams. Applied Mechanics and Materials. 2014. Vol. 578-579. Pp. 858-863.

32. Lalin V.V., Rybakov V.A. Konechnyye elementy dlya rascheta ograzhdayushchikh konstruktsiy iz tonkostennykh profiley[Finite elements for the calculation of protecting designs from thin-walled profiles]. Magazine of Civil Engineering. 2011. No. 8(26). Pp. 69-80. (rus)

33. Lukashevich A.A., Rozin L.A. O reshenii kontaktnykh zadach stroitelnoy mekhaniki s odnostoronnimi svyazyami i treniyem metodom poshagovogo analiza [Solution of contact problems of structural mechanics with unilateral constraints and friction by step analysis]. Magazine of Civil Engineering. 2013. No. 1(36). Pp. 75-81. (rus)

34. Tyukalov Yu.Ya. Resheniye ploskoy zadachi teorii uprugosti metodom konechnykh elementov $v$ napryazheniyakh [The solution a flat problem of of elasticity theory of finite element method in stresses]. Structural Mechanics and Analysis of Constructions. 2006. No. 2. Pp. 34-38. (rus)

35. Tyukalov Yu.Ya. Variatsionno-setochnyy metod resheniya ploskoy zadachi teorii uprugosti $v$ napryazheniyakh [Variational-grid method for the solution a flat problem of of elasticity theory in stresses]. Structural Mechanics and Analysis of Constructions. 2006. No. 3. Pp. 44-49. (rus)

36. Tyukalov Yu.Ya. Variatsionno-setochnyy metod resheniya zadach izgiba plit $v$ napryazheniyakh [Variational-grid method for solving the plate bending problems in stresses]. Izvestiya vuzov. Stroitelstvo. 2006. No. 8. Pp. 13-20. (rus)

37. Tyukalov Yu.Ya. Raschet obolochek proizvolnoy formy metodom konechnykh elementov $v$ napryazheniyakh [Calculation of arbitrary form shells using finite element method in stresses]. Structural Mechanics and Analysis of Constructions. 2006. No. 1. Pp. 65-74. (rus)

38. Tyukalov Yu.Ya. Ispolzovaniye kusochno-postoyannykh napryazheniy dlya resheniya obyemnykh zadach teorii uprugosti [Using the piecewise constant stresses for solutions of the volumetric elasticity problems]. Izvestiya vuzov. Stroitelstvo. 2008. No. 4. Pp. 4-9. (rus)

Yury Tyukalov,

+7(912)8218977; yutvgu@mail.ru design of frame of thin-walled beams // Applied mechanics and materials. 2014. Vol. 578-579. Pp. 858-863.

32. Лалин В.В., Рыбаков В.А. Конечные элементы для расчета ограждающих конструкций из тонкостенных профилей // Инженерно-строительный журнал. 2011. № 8(26). С. 69-80.

33. Лукашевич А.А., Розин Л.А. О решении контактных задач строительной механики с односторонними связями и трением методом пошагового анализа // Инженерно-строительный журнал. 2013. № 1(36). C. $75-81$.

34. Тюкалов Ю.Я. Решение плоской задачи теории упругости методом конечных элементов в напряжениях // Строительная механика и расчет сооружений. 2006. № 2. С. 34-38.

35. Тюкалов Ю.Я. Вариационно-сеточный метод решения плоской задачи теории упругости в напряжениях // Строительная механика и расчет сооружений. 2006. № 3. С. 44-49.

36. Тюкалов Ю.Я. Вариационно-сеточный метод решения задач изгиба плит в напряжениях // Известия вузов. Строительство. 2006. № 8. С. 13-20.

37. Тюкалов Ю.Я. Использование кусочно-постоянных напряжений для решения объемных задач теории упругости // Известия вузов. Строительство. 2008. № 4. C. 4-9.

38. Тюкалов Ю.Я. Расчет оболочек произвольной формы методом конечных элементов в напряжениях // Строительная механика и расчет сооружений. 2006. № 1. С. $65-74$.

Tyukalov Yu.Ya., 2016

Tyukalov Yu.Ya. Stress finite element models for determining the frequencies of free oscillations. Magazine of Civil Engineering. 2016. No. 7. Pp. 39-54. doi: 10.5862/MCE.67.5 